\title{
YESUS SEBAGAI MODEL GEMBALA SEJATI DAN RELASINYA TERHADAP GEMBALA SEBAGAI PENDIDIK
}

\author{
Indro Puspito*1 \\ ${ }^{1}$ Sekolah Tinggi Anak Bangsa Surabaya \\ *indropuspito@gmail.com
}

\begin{abstract}
The need for quality leaders who are expected to be able to shepherd believers is enormous. This urgent need dates back to the very real work of the Holy Spirit in Acts. The problem that arises is: What is the meaning of the person of the Shepherd? How is the pastor's job as an educator who teaches the church? How is Jesus as a Model of the True Shepherd and his relationship to the Shepherd as an Educator? The answer: (1) The pastor of the church is someone whose job is to care for, care for, feed and who has a relationship with the people he serves. (2) The pastor's duties as education that teaches the church are: to feed, care for, and lead. (3) The image of Jesus as a model of the shepherd is used as a means of material for the teaching and learning process both for himself as an educator and for his congregation so that both the educator and the congregation can change according to the characteristics of the true shepherd, Jesus Christ.
\end{abstract}

Keywords: Jesus, model, pastor, educator

\begin{abstract}
Abstrak
Kebutuhan akan pemimpin yang berkualitas dan diharapkan mampu menggembalakan orangorang percaya, begitu besar. Kebutuhan yang mendesak ini sudah dimulai sejak pekerjaan Roh Kudus yang begitu nyata dalam Kisah Para Rasul. Persoalannya yang timbul adalah: Apakah yang dimaksud dengan pribadi Gembala? Bagaimanakah tugas gembala sebagai pendidik yang mengajar jemaat? Bagaimanakah Yesus sebagai Model Gembala Sejati dan relasinya terhadap Gembala sebagai Pendidik? Jawabnya: (1) Kepribadian Gembala jemaat adalah seseorang yang pekerjaannya menjaga, memelihara, memberi makan dan yang memiliki hubungan dengan orang-orang yang dilayaninya. (2) Tugas gembala sebagai pendidikan yang mengajar jemaat adalah: memberi makan, memelihara, dan memimpin. (3) Gambaran Yesus sebagai model gembala digunakan sebagai sarana materi proses belajar mengajar baik terhadap dirinya sebagai pendidik mapun terhadap jemaatnya agar baik pendidik maupun jemaat terjadi perubahan sesuai dengan karakteristik gembala sejati adalah Yesus Kristus.
\end{abstract}

Kata kunci: Yesus, model, gembala, pendidik 


\section{PENDAHULUAN}

Sosok gembala dan pekerjaannya di tahun-tahun ini semakin mendapat perhatian serius seiring dengan "ledakan pertumbuhan gereja di abad ke-21 hingga memasuki milenium ke-3 ini sungguh dasyat. Multiplikasi orang percaya selama abad ini melebihi jumlah orang kristen seutuh abad sebelumnya. Dimulai dari 12 murid, kini mencapai 2,1 milyar lebih. ${ }^{1}$ Kebutuhan akan pemimpin yang berkualitas yang berharap mampu menggembalakan orang-orang percaya, begitu besar. Kebutuhan yang mendesak ini sudah dimulai sejak pekerjaan Roh Kudus yang begitu nyata dalam Kisah Para Rasul. Ledakan orang yang percaya kepada berita keselamatan yang disampaikan rasul Petrus, telah mengejutkan dunia.

$\begin{array}{cccc}\text { Kisah } & \text { Para } & \text { Rasul } & 2: 37-41 \\ \text { mengatakan } & \text { bahwa } & \text { ketika } & \text { mereka }\end{array}$
mendengar hal itu hati mereka sangat terharu, lalu mereka bertanya kepada Petrus dan rasul-rasul yang lain: "Apakah yang harus kami perbuat, saudara-saudara?" Jawab Petrus kepada mereka: "Bertobatlah dan hendaklah kamu masing-masing memberi dirimu dibaptis dalam nama Yesus Kristus untuk pengampunan dosamu, maka kamu akan menerima karunia Roh Kudus. Sebab bagi kamulah janji itu dan bagi anakanakmu dan bagi orang yang masih jauh, yaitu sebanyak yang akan dipanggil oleh Tuhan Allah kita." Dan dengan banyak perkataan lain lagi ia memberi suatu kesaksian yang sungguh-sungguh dan ia mengecam dan menasihati mereka, katanya: "Berilah dirimu diselamatkan dari angkatan yang jahat ini." Orang-orang yang menerima perkataannya itu memberi diri dibaptis dan pada hari itu jumlah mereka bertambah kirakira tiga ribu jiwa.

Setelah rasul Petrus berkotbah, tiga ribu orang bertobat. Berbagai masalah mulai

\footnotetext{
${ }^{1}$ G. Sudarmanto, Menjadi Pelayan Kristus yang Baik (Malang: YPPII, 2009), vi. 88 | Vol. 4 No. 2 (Desember 2020)
}

muncul, oleh sebab itu para rasul mulai membagi tugas untuk memenuhi berbagai kebutuhan orang-orang percaya. Kebutuhan akan pelayanan penggembalaan diperlukan dengan segera.

Kisah Para Rasul 6:1-6 mengatakan bahwa pada masa itu, ketika jumlah murid makin bertambah, timbullah sungut-sungut di antara orang-orang Yahudi yang berbahasa Yunani terhadap orang-orang Ibrani, karena pembagian kepada jandajanda mereka diabaikan dalam pelayanan sehari-hari. Berhubung dengan itu kedua belas rasul itu memanggil semua murid berkumpul dan berkata: "Kami tidak merasa puas, karena kami melalaikan Firman Allah untuk melayani meja. Karena itu, saudarasaudara, pilihlah tujuh orang dari antaramu, yang terkenal baik, dan yang penuh Roh dan hikmat, supaya kami mengangkat mereka untuk tugas itu, dan supaya kami sendiri dapat memusatkan pikiran dalam doa dan pelayanan Firman." Usul itu diterima baik oleh seluruh jemaat, lalu mereka memilih Stefanus, seorang yang penuh iman dan Roh Kudus, dan Filipus, Prokhorus, Nikanor, Timon, Parmenas dan Nikolaus, seorang penganut agama Yahudi dari Antiokhia.

Mereka itu dihadapkan kepada rasulrasul, lalu rasul-rasul itupun berdoa dan meletakkan tangan di atas mereka. Waktu itu, para rasul mulai membagi tugas hanya dengan dua kriteria yaitu pelayanan rohani dan pelayanan jasmani. Para rasul menyerahkan pelayanan jasmani kepada team yang terdiri dari tujuh orang sedangkan mereka fokus dalam pelayanan rohani, yatiu mengajar jemaat.

Masalah-masalah yang mereka hadapi tidak hanya berhenti di dua area itu saja tetapi berkembang ke masalah-masalah lain, yaitu "kehancuran Moral dan penyesatan dokrinal (ajaran). ${ }^{2}$ Masalahmasalah itu sudah mulai muncul di jaman para rasul memimpin juga di jaman rasul Paulus. Dalam berbagai kotbah dan 
tulisannya, para rasul mendidik jemaat untuk memahami pengajaran yang benar dan bagaimana mengaplikasikannya dalam kehidupan sehari-hari. Para rasul menulis: "Sebab adalah keputusan Roh Kudus dan keputusan kami, supaya kepada kamu jangan ditanggungkan lebih banyak beban dari pada yang perlu ini: kamu harus menjauhkan diri dari makanan yang dipersembahkan kepada berhala, dari darah, dari daging binatang yang mati dicekik dan dari percabulan. Jikalau kamu memelihara diri dari hal-hal ini, kamu berbuat baik. Sekianlah, selamat" (Kis.15:28-29).

Rasul paulus juga menulis: Karena itu, saudara-saudara, demi kemurahan Allah aku menasihatkan kamu, supaya kamu mempersembahkan tubuhmu sebagai persembahan yang hidup, yang kudus dan yang berkenan kepada Allah: itu adalah ibadahmu yang sejati. Janganlah kamu menjadi serupa dengan dunia ini, tetapi berubahlah oleh pembaharuan budimu, sehingga kamu dapat membedakan manakah kehendak Allah: apa yang baik, yang berkenan kepada Allah dan yang sempurna (Rm. 12:1-2).

Para rasul punya peran yang besar dalam menolong orang-orang percaya menjadi orang-orang yang terdidik dan bertumbuh secara rohani dan hal ini membuat "jemaat bersukacita karena isinya yang menghiburkan" (Kis. 15:31). Dari abad ke abad, kebutuhan akan adanya gembala untuk memimpin jemaat bukannya semakin surut, melainkan semakin banyak dan semakin dituntut memiliki kualitas yang tinggi. Banyak jemaat maupun denominasi gereja, berdoa dan mencari pemimpin jemaat. Bahkan banyak juga lembaga gereja yang mempersiapkan para pemimpinnya dengan membuat sekolah teologia sendiri dan memang sepatutnya demikian.

Di pihak Tuhan, Diapun "mencari orang-orang yang dapat diangkat-Nya menjadi pemimpin."3 Kata "mencari" bukan berarti sebelumnya tidak ada orang yang akan ditunjuk untuk memimpin, tetapi lebih cenderung kepada menunggu orang-orang yang sudah dipilihnya untuk dipersiapkan. Menunggu sampai persiapannya selesai dan siap melayani sebagai gembala yang mampu memimpin jemaat yang akan "mengepalai, mengetuai, memandu, memegang tangan seseorang untuk dibimbing dan ditunjukkan jalan; melatih, mendidik, mengajar agar dapat mengerjakan sendiri. ${ }^{4}$

Kata "persiapan" ini begitu penting untuk sebuah pekerjaan pelayanan memimpin jemaat karena begitu kompleksnya tugas dan tanggung jawab yang harus dipikul. Kalau persiapannya cukup, maka gembala akan berjalan sesuai dengan fungsinya.

Tujuan penulisan menjawab pertanyaan: Apakah yang dimaksud dengan pribadi Gembala? Bagaimanakah tugas gembala sebagai pendidik yang mengajar jemaat? Bagaimanakah Yesus sebagai Model Gembala Sejati dan relasinya terhadap Gembala sebagai Pendidik?

\section{METODE}

Penelitian ini menggunakan metode kualitatif dengan pendekatan deskriptif dan studi pustaka, bertujuan untuk menyajikan informasi $^{5}$ dengan metode untuk menggambarkan suatu hasil penelitian. Namun, hasil gambaran tersebut tidak digunakan untuk membuat kesimpulan yang lebih umum.

${ }^{3}$ Ralph Mahoney, Pembentukan Seorang Pemimpin (Glenoaks, Burbank, USA: World Missionary Assistance Plan, n.d.), 88.

${ }^{4}$ Ernie Tisnawati Sule \& Kurniawan Saefullah, Pengantar Manajemen (Jakarta: Prenada Media, 2005), 255.

${ }^{5}$ H.B. Sutopo, Metodologi Penelitian Kuantitatif (Surakarta: Universitas Sebelas Maret Press, 2006), 25. 


\section{PEMBAHASAN}

\section{Pribadi Gembala}

Untuk menjadi seorang pemimpin tidaklah sederhana dan mudah, karena seorang pemimpin itu tidak hanya bertanggung jawab pada dirinya sendiri tetapi juga kepada banyak orang yang dipimpinnya. Ada banyak syarat yang harus dipenuhinya dan mentaati segala ketetapan yang sudah digariskan kepadanya. ${ }^{6}$ Syaratsyarat yang sudah dipenuhi, akan menjadikan sosok pemimpin yang berkualitas. Jadi antara seseorang yang menjabat sebagai pemimpin jemaat dan kualitas pribadinya, harus sesuai dengan kriteria yang Alkitab tetapkan.

Dalam Alkitab, ada dua macam jenis gembala, yaitu: pertama, orang yang mengembalakan ternak. Kedua, orang yang mengasuh dan membina manusia, yaitu gembala yang bersifat ilahi maupun fana."7 Berkenaan dengan orang yang menggembalakan ternak, "tugas seorang gembala sungguh berat. Dari pagi sampai malam gembala berjalan bersama kawanan dombanya untuk mencari rumput dan sumur untuk mengambil air minum pada siang hari. Tetapi, bukan hanya itu saja, baca Samuel 17:34-36, dimana Daud melukiskan apa yang dilakukannya sebagai gembala, ia tidak takut singa atau beruang, tetapi berjuang sampai ia berhasil menyelamatkan domba atau kambing yang mau dirampas dan dibunuh oleh hewan buas." 8

Sedangkan kalau yang berhubungan dengan orang yang Mengasuh dan membina orang lain. Dalam Yohanes 21:15-19 menceritakan bahwa kepada orang percaya bagai mana Yesus berpesan kepada Petrus untuk memelihara domba-domba-Nya, yang akan ditinggalkan-Nya. Yesus sendiri

\footnotetext{
${ }^{6}$ Yakobus Handjojo Wijaya, Ikabot Kemulian Allah yang Lenyap (Jakarta: 2005), 64.

${ }^{7}$ J. D Douglas, Ensiklopedi Alkitab Masa Kini Jilid 1 A-L (Jakarta: Yayasan Komunikasi Bina Kasih/OMF, 2002), 330.

${ }^{8}$ M. Bons-Strom, Apakah Pengembalaan Itu? (Jakarta: BPK Gunung Mulia, 2011), 3-4.
}

90 | Vol. 4 No. 2 (Desember 2020) mengibaratkan atau menyamakan pelayanan kepada saudara-saudara kita dalam diri-Nya itu, dengan pengembalaan."

\section{Definisi Gembala}

Kata "gembala" diartikan sebagai: (1) penjaga atau pemiara binatang (ternak), dan (2) penjaga keselamatan orang banyak. Orang yang pekerjaannya menggembala kerbau;" "Dalam konteks menggembalakan jemaat berarti orang yang menjaga dan memelihara orang-orang percaya. ${ }^{11}$ Dalam bahasa Inggris, kata "shepherd" (gembala) berakar dari kata "sheep" (domba). Tetapi dalam bahasa Ibrani kuno, kata "gembala" tidak berakar dari kata "domba", melainkan dari kata "memberi makan". Kata Ibrani untuk "gembala" ialah "ra' ah". Kata ini dibentuk dari kata "memberi makan". Akibatnya, gembala dikenal sebagai "orang yang memberi makan."12 Dalam konteks menggembalakan jemaat berarti mengajarkan firman Tuhan sebagai makanan rohani untuk kesehatan rohani jemaat. Atau dalam istilah lain disebut "penerapan khusus Injil kepada anggota jemaat secara pribadi, yaitu berita Injil yang dalam khotbah gereja disampaikan kepada semua orang. ${ }^{13}$

Menurut H. Faber mengatakan bahwa penggembalaan adalah "tiap-tiap pekerjaan, yang di dalamnya, si pelayan sadar akan akibat yang ditimbulkan oleh percakapannya, atau khotbahnya, atas kepribadian orang, yang pada saat itu di hubunginya. Maka yang terpenting adalah hubungan atau relasi antara pelayan dan anggota jemaatnya. Kedua hal itu dapat ditemukan juga dalam perumpamaan tentang gembala yang baik (Yoh. 10;1-21). Seorang gembala yang baik mengenal

\footnotetext{
${ }^{9}$ Ibid.

${ }^{10}$ http://kbbi.web.id/gembala

11" gembala", Kamus Besar Bahasa

Indonesia. CD-ROM. Offline. Versi 1.5.1.

${ }^{12}$ Oliver Mc Mahan, Gembala Jemaat yang Sukses (Jakarta: Sinode GBI Jakarta, 2002), 5.

${ }^{13} \mathrm{M}$. Bons Strom, Apakah Pengembalaan Itu? 1-3.
} 
Dombanya satu persatu (ay. 14). ${ }^{14}$ Jadi gembala jemaat adalah seseorang yang pekerjaannya menjaga, memelihara, memberi makan dan yang memeliki hubungan dengan orang-orang yang dilayaninya.

\section{Pribadi Gembala Sejati}

Alkitab mencatat berbagai macam kriteria seorang pemimpin yang menggembalakan atau seorang gembala yang memimpin jemaat. Kriteria dasar yang dicatat dalam 1 Timotius adalah mengenai pribadi atau karakternya. Dalam 1 Timotius 3:1-7 mengatakan bahwa: "Orang yang menghendaki jabatan penilik jemaat menginginkan pekerjaan yang indah." Karena itu penilik jemaat haruslah seorang yang tak bercacat, suami dari satu isteri, dapat menahan diri, bijaksana, sopan, suka memberi tumpangan, cakap mengajar orang, bukan peminum, bukan pemarah melainkan peramah, pendamai, bukan hamba uang, seorang kepala keluarga yang baik, disegani dan dihormati oleh anak-anaknya. Jikalau seorang tidak tahu mengepalai keluarganya sendiri, bagaimanakah ia dapat mengurus Jemaat Allah? Janganlah ia seorang yang baru bertobat, agar jangan ia menjadi sombong dan kena hukuman Iblis. Hendaklah ia juga mempunyai nama baik di luar jemaat, agar jangan ia digugat orang dan jatuh ke dalam jerat Iblis.

Jadi setiap gembala harus memperhatikan bagaimana membangun diri sendiri, karena "kepemimpinan dimulai dari dalam lalu keluar."15 Gembala harus memperhatikan karakternya sendiri sebelum memperhatikan karakter orang lain. gembala harus berani menasehati dirinya sendiri sebelum menasehati orang lain.

Seperti sebuah kereta api, bagian depan adalah kepala setelah itu baru banyak gerbong, demikian juga karakter adalah

\footnotetext{
${ }^{14}$ Ibid., 3-4.

${ }^{15}$ John Maxwell, A Leader's Heart (Bandung: Pionir Jaya, 2011), 80.
}

kepala dan talenta adalah gerbongnya, maka "karakter mendahului talenta."16 Karakter harus di depan setelah itu gerbong yaitu telenta, mengikutinya. Karena "talenta adalah anugerah, tapi karakter adalah pilihan,"17 maka Keputusan untuk mendahulukan persiapan karakter sebelum mengembangkan talenta adalah bagian gembala itu sendiri.

Fokus awal ke karakter ini bukan merupakan tindakan jalan di tempat, sebaliknya merupakan tindakan yang bijaksana karena "jika saya mengurus karakter saya, maka reputasi saya akan mengurus dirinya sendiri."18 Reputasi akan selalu mengikuti seiring dengan pertumbuhan karakter seorang gembala.

\section{Memiliki Hati yang Melayani}

Hati yang melayani cenderung berbicara tentang sikap, yaitu the inner man, sesuatu yang didalam manusia dan bukan berbicara tentang talenta maupun jabatan yang kelihatan di luar. Sikap hati yang mau melayani orang lain, mendahulukan kepentingan orang lain dari pada kepentingan diri sendiri. Segala tindakan yang dilakukan bukan dimotivasi karena mencari perhatian, untuk mendapat kedudukan atau nama maupun mencari pengaruh.

Hati yang melayani merupakan dasar yang harus dimiliki oleh setiap gembala yang terjun dalam pekerjaan melayani jemaat. Denis Waitly (seperti yang dikutip oleh John Maxwell), mengatakan kalau "kelebihan seorang pemimpin bukan pada bakat bawaannya, IQ nya yang tinggi, atau talentanya. Kelebihan seorang pemimpin adalah sikapnya bukan kemampuan"19

Hati yang melayani adalah sikap yang rela memberi hidup kepada orang lain "dan di mana ada kerelaan serta kesukaan

\footnotetext{
${ }^{16}$ Ibid., 302.

${ }^{17}$ Ibid., 117.

${ }^{18}$ http://kingdomcommunication.blogspot.co .id/2008_03_01_archive.html.

${ }^{19}$ John Maxwell, A Leader's Heart, 23.
} 
melayani, di situlah pemimpin dan sekaligus pelayanan yang sejati. Pelayanan dan kepemimpinan harus dimulai dari hati yang tergerak oleh iba (compassion) yang tulus dan spontan kepada orang banyak. Melayani itu lebih dari sekedar melakukan sesuatu dengan baik. ${ }^{20}$

Hati yang melayani "seorang pelayan Tuhan yaitu seorang yang melayani pekerjaan Tuhan. Bukan saja ia harus mempunyai pengetahuan dan kecakapan dalam pekerjaan yang ia jalankan, tetapi dibelakang tugasnya itu adalah seluruh kepribadiannya. Tuhan Yesus dalam Matius 5:3-9 menyiratkan seorang pelayan Tuhan (murid Kristus) harus: rendah hati, hancur hati, lembut hati, lapar dan haus akan kebenaran, menaruh kasihan, suci hati, damai hati. $" 21$

Hati yang melayani juga kuat di dalam empati. Spears pada tahun 1995 melakukan studi indikator kehadiran pemimpin yang melayani terlihat dari 10 hal berikut: "(1) Kesediaan untuk menyimak, (2) Kuat dalam empati, (3) Melakukan pemulihan-pemulihan, (4) Penyadaran/ peningkatan kesadaran, (5) Memiliki sikap persuasif, (6) Mampu membuat konsep, (7) Mampu membuat perkiraan yang tepat, (8) Penatalayanannya baik, (9) Memiliki komitmen untuk menghasilkan proses pembelajaran, (10) Serius dalam upaya pembentukan dan pengembangan komunitas. $" 22$

\section{Memiliki Integritas}

Kamus merriam Webster menerangkan arti dari integritas (inggris: integrity) adalah the quality of being honest and fair, the state of being complete or

${ }^{20}$ Eka Darmaputera, Kepemimpinan dalam Perspektif Alkitab (Yogyakarta: Kairos, 2005), 84-85.

${ }^{21}$ H.L. Senduk, Pelayan Tuhan (Jakarta: Yayasan Bethel, 2010), 1-3.

${ }^{22}$ Robby Chandra, Landasan Pacu Kepemimpinan (Yogyakarta: Gloria Graffa, 2005), 61-62.

92 | Vol. 4 No. 2 (Desember 2020) whole. $^{23}$ Sedangkan dalam kamus bahasa Indonesia, arti dari integritas adalah mutu, sifat, atau keadaan yang menunjukkan kesatuan yang utuh sehingga memiliki potensi dan kemampuan yang memancarkan kewibawaan; kejujuran. ${ }^{24}$ "Pemimpin dengan integritas adalah seorang yang mempunyai kepribadian utuh dalam kata dan perbuatan. Sebagaimana perilakunya di depan umum, begitulah kenyataan kehidupannya. Sebagai seorang pemimpin, ia selalu melakukan apa yang dikatakannya dan mengatakan apa yang dilakukannya. Integritas merupakan tulang punggung dari seorang pemimpin Kristen." ${ }^{25}$ Dengan kata lain, "seseorang yang punya integritas tidak membagi loyalitas (itu sikap mendua), ataupun dia hanya pura-pura (itu kemunafikan). Orang yang memiliki integritas adalah orang yang utuh; mereka bisa diidentifikasi dengan kesatuan pikirannya. Orang yang memiliki integritas tidak punya apa pun untuk disembunyikan dan tidak punya apa pun untuk ditakuti." 26

Selanjutnya John Stott berpendapat bahwa "integritas adalah ciri orang-orang yang terintegrasi secara selaras, yang di dalam dirinya tidak ada dikotomi antara kehidupan pribadi dan kehidupan di muka umum, antara yang disaksikan dan yang diterapkan, antara yang diucapkan dan yang dilakukan. Integritas merupkan ciri esensial dari seorang pemimpin dan yang terpenting dari para penginjil.'”

Sedangkan John Maxwell dalam bukunya A Leader's Heart, menulis kalau "Integritas adalah tentang hal kecil." ${ }^{28}$ Hal-

${ }^{23}$ http://www.merriam-

webster.com/dictionary/integrity.

${ }^{24} \mathrm{http}: / /$ kamusbahasaindonesia.org/integritas

${ }^{25}$ Bambang Yudho, How to Become A Christian Leader (Yogyakarta: Yayasan Andi, 2006), 20.

${ }^{26}$ John C. Maxwell, Mengembangkan Kepemimpinan di dalam Diri Anda (Jakarta: Binarupa Aksara,1995), 38.

${ }^{27}$ Jonathan Lamb, Integritas (Jakarta: Perkantas, 2008), 14.

${ }^{28}$ John Maxwell, A Leader's Heart, 225. 
hal kecil yang tetap dianggap serius untuk dipertanggungjawabkan kepada Tuhan walaupun tidak kelihatan atau tidak dihargai oleh orang lain.

Jadi integritas itu adalah seseorang yang ada di hati dan dalam tindakan itu sama (tidak menipu diri sendiri dan orang lain), apa yang diucapkan dan dilakukan itu sama, tidak ada sesuatu yang disembunyikan dan ditakuti (hidup apa adanya), dan melakukan hal-hal yang kecil sekalipun dengan penuh tanggung jawab walaupun tidak dilihat orang.

Bagaimana dengan integritas gembala sebagai pemimpin rohani atau pemimpin rohani yang menggembalakan jemaat, apakah selama ini jemaat atau orang diluar jemaat mendapatinya? James Kouzes dan Barry Posner dalam buku mereka berjudul Credibility: How Leaders Gain and Lose It, Why People Demand It (seperti yang dikutip oleh Senjaya), melaporkan hasil riset mereka selama ampir 20 tahun dari survey terhadap ribuan kaum profesional dari empat benua bahwa "karakteristik nomor satu yang paling kritis bagi seorang pemimpin adalah integritas." 29 Sedangkan Jonathan Parapak dalam kata pengantarnya pada buku Integritas: "Memimpin di bawah pengamatan Tuhan" yang ditulis oleh Jonathan Lamb juga melihat hal yang sama. Dia mengatakan bahwa "lebih memprihatinkan lagi berkembangnya masalah perpecahan dan bentrokan dalam berbagai institusi kristiani bahkan di gereja yang disebabkan masalah korupsi dan integritas para pejabatnya." 30

Kalau seorang pemimpin kehilangan integritas maka lambat laun akan jatuh ke dalam berbagai macam dosa. Yakobus Handjojo Wijaya dalam bukunya yag berjudul Ikabot (Kemuliaan yag lenyap menyatakan bahwa: "Sangat menyedihkan

\footnotetext{
${ }^{29}$ Sendjaya, Kepemimpinan Kristen (Yogyakarta: Kairos, 2004), 62.

${ }^{30}$ Jonathan Lamb, Integritas (Jakarta:

Perkantas, 2008), 17.
}

memang kejatuhan dari pada hamba-hamba Tuhan atau pemimpin rohani yang sudah pernah dipakai oleh Tuhan ini. Iblis memakai sex dalam bentuk perzinahan, perselingkuhan (bagi yang sudah berkeluarga) pergaulan bebas (free sex, free love, khususnya kaum muda) ada juga hamba Tuhan yang menjadi homo secara tersamar maupun lesbi."31

Kalau seorang pemimpin sudah jatuh dalam dosa, maka dia akan kehilangan segala-galanya, seperti yang Billy Graham katakan (seperti yang dikutip oleh John C. Maxwell), "Integritas adalah lem yang merekatkan cara hidup kita menjadi satu. Kita harus terus-menerus berjuang untuk menjaga agar integritas kita tetap utuh". Ketika kekayaan hilang, tidak ada apa pun yang hilang; ketika kesehatan hilang, sesuatu hilang; ketika watak hilang, segalagalanya hilang. ${ }^{32}$

Sebaliknya, dalam pelayanan, keberhasilan seorang gembala jemaat yang tugas utamanya adalah memimpin jemaat pada suatu tujuan, akan tercapai dengan maksimal bila jemaat melihat integritasnya. John C. Maxwell mengatakan delapan puluh persen dari apa yang dipelajari orang datang melalui stimulasi visual, 10 persen melalui stimulasi pendengaran, dan 1 persen melalui indera lainnya." 33

Selanjutnya, Maxwell menerangkan bahwa "merupakan hal yang masuk akal bahwa semakin banyak pengikut melihat dan mendengar pemimpinnya konsisten dalam tindakan dan perkataan, akan semakin besar pula konsistensi dan loyalitas mereka. Apa yang mereka dengar, mereka pahami. Apa yang mereka lihat, mereka percayai. Terlalu sering kita berusaha memotivasi pengikut kita dengan sarana yang cepat mati dan dangkal. Yang diperlukan orang

\footnotetext{
${ }^{31}$ Yakobus Handjojo Wijaya, Ikabot kemulian Allah yang Lenyap, 6.

${ }^{32}$ John C. Maxwell, Mengembangkan Kepemimpinan di dalam Diri Anda, 48.

${ }^{33}$ Ibid., 40 .
} 
bukanlah motto untuk dikatakan, melainkan teladan untuk dilihat. ${ }^{34}$

\section{Memiliki Waktu Pribadi untuk Berdoa}

Setiap gembala yang akan memimpin jemaat, selain harus berjuang untuk memiliki hati yang melayani dan memiliki integritas, juga harus memiliki waktu-waktu yang khusus untuk berdoa. Memang akan banyak hal yang akan membuat seorang pemimpin menjadi sibuk, sibuk, dan sangat sibuk, apalagi kalau pelayanan semakin besar, tetapi tetap harus mengambil keputusan untuk memiliki waktu sendirian bersama Tuhan, yaitu berdoa.

Ada begitu banyak alasan mengapa seorang gembala yang memimpin jemaat harus memiliki waktu untuk berdoa, tetapi penulis akan menguraikan beberapa hal yang penting mengapa harus berdoa. Yang pasti, seorang pemimpin harus membuat keputusan untuk mengadakan atau mengalokasikan waktu-waktu tertentu untuk berdoa karena "Kedekatan Anda dengan Allah bergantung pada pilihan Anda." ${ }^{\text {"35 }}$ Indikator kebersamaan dengan Allah dalam doa sebagai berikut:

Pertama, doa, tanda penyerahan diri. Memiliki kerinduan untuk melayani Tuhan itu adalah bagian dari hidup yang indah dan luarbiasa. Tuhanpun juga senang kalau mendapati hamba-hamba-Nya melayani dengan motivasi yang benar, tetapi melayani pekerjaan Tuhan di gereja, tidak semudah dan semulus yang dibayangkan.

Walaupun melayani jemaat dengan hati yang tulus dan dengan segenap kekuatan, hal itu tidak menghindarkan seorang gembala dari masalah-masalah yang datang dari jemaat yang tidak puas, kecewa, salah mengerti, dsb. Hal ini tentu akan memukul balik pemimpin itu sendiri, gembala akan merasa tertolak, tidak dihargai, kecewa, dan lainnya.

Dengan berdoa, gembala menyerahkan hidup dan pelayanannya kepada Tuhan yang mengutusnya dan yang

\footnotetext{
${ }^{34}$ Ibid., 40.

${ }^{35}$ Rick Warren, The Purpose Driven Life (Malang: Gandum Mas, 2005), 96. 94 | Vol. 4 No. 2 (Desember 2020)
}

memiliki jemaat. "Doa adalah suatu tindakan penyerahan yang membawa hal-hal mengerikan menyakitkan, mustahil dan menyerahkannya kepada Allah, menyerahkan kendali kepada Allah, yang bekerja di dalam dan melalui segala sesuatu. $^{36}$ Dengan berdoa, seorang pemimpin seakan-akan berkata kepada Tuhan "jadilah kehendak-Mu seperti apa yang Engkau mau." Matius 26:39 mengatakan bahwa maka Ia maju sedikit, lalu sujud dan berdoa, kata-Nya: "Ya Bapa$\mathrm{Ku}$, jikalau sekiranya mungkin, biarlah cawan ini lalu dari pada-Ku, tetapi janganlah seperti yang Kukehendaki, melainkan seperti yang Engkau kehendaki."

Kedua, doa, tanda mau diubahkan. Dengan memiliki hati yang berserah, hal itu seperti seseorang yang mengangkat tangan dan meminta Tuhan turun tangan. Dengan memiliki hati yang berserah, memudahkan Tuhan bekerja didalam diri hamba Tuhan dan melalui hidupnya. Dalam Roma 8:28-29 dikatakan bahwa We know that in all things God works for good with those who love him, those whom he has called according to his purpose. Those whom God had already chosen he also set apart to become like his Son, so that the Son would be the first among many believers. Dalam segala hal berarti hal-hal yang baik juga hal-hal yang tidak baik menurut manusia, digunakan Tuhan untuk membentuk manusia serupa dengan-Nya. "Ketika kita berdoa, maka Allah dengan perlahan-lahan dengan penuh rahmat akan menyatakan tempat-tempat persembunyian kita dan melepaskan kita dari tempat-tempat itu.",37 Hal-hal yang jelek, diubahkan menjadi hal-hal uang baik sedangkan hal-hal yang baik, dibuat lebih baik lagi hingga sempurna seperti Dia.

Ketiga, doa, tanda minta tuntunan Tuhan. Teresa Tay dalam bukunya "Menjangkau Hati Bapa" mengutip

\footnotetext{
${ }^{36}$ Jay Dennis, Eksperimen Doa (Jakarta: Immanuel, 2002), 76.

${ }^{37}$ Richard J. Foster, Tertib Doa (Malang: Gandum Mas, 1990), 54.
} 
penelitian yang dilakukan oleh Institut Pertumbuhan Gereja di Fuller Seminari di Pasadena, menyebutkan bahwa: 90\% pendeta bekerja lebih dari 64 jam seminggu, $80 \%$ percaya bahwa pelayanan penggembalaan telah berdampak negatif kepada keluarga mereka, 33\% berkata bahwa pelayanan merupakan bahaya bagi keluarga mereka, $75 \%$ melaporkan krisis berkaitan dengan akibat beratnya tekanan pribadi setidaknya satunkali di dalam pelayanan mereka, 50\% merasa tidak mampu untuk memenuhi kebutuhan tugas mereka, 90\% merasa bahwa mereka tidak cukup terlatih untuk memenuhi tuntutan pelayanan, $70 \%$ berkata bahwa kepercayaan diri mereka sekarang sedang menurun dibandingkan ketika mereka mulai pelayanan, $40 \%$ melaporkan konflik serius dengan seorang anggota gereja dan setidaknya sekali sebulan, dan $70 \%$ tidak memiliki seorang yang mereka anggap sebagai teman dekat. ${ }^{38}$

Selanjutnya menurut Teresa Tay, "perbedaan antara pendeta yang ada kepedihan dan kekelaman dengan pendeta yang keadaannya baik-baik saja bukan karena mereka lebih pandai atau keadaan yang lebih baik. Perbedaan mereka adalah bahwa mereka memiliki tudung doa yang lebih luas." 39

Betapa pentingnya berdoa bagi seorang gembala. Berdoa adalah salah satu bentuk ketergantungan pemimpin kepada Tuhan. Dengan berdoa, seorang gembala menyadari bahwa hanya Gembala Agung sendiri yang mampu memimpin jemaat untuk mencapai tujuan. Dengan berdoa, gembala menyadari bahwa dia hanyalah alat atau kepanjangan tangan sang Gembala Agung.

Melalui berdoa, seorang gembala akan mendapat arahan dari Tuhan untuk gereja lokalnya sendiri. Gereja tidak didesain untuk menirukan program gereja

\footnotetext{
${ }^{38}$ Teresa Tay, Menjangkau Hati Bapa, 46.

${ }^{39}$ Ibid., 45.
}

lain, tetapi setiap gereja adalah untik dan Tuhan memiliki pola sendiri "bila gereja menjalankan penggembalaan sesuai dengan desain yang Allah maksudkan di dalam Alkitab, maka kepemimpinan gembala tidak pernah usang, melainkan selalu "up to date." 40

Ketika berdoa, gembala sedang meminta Tuhan memberikan tujuan dan cara mencapainya kepada Tuhan. John Maxwell menulis: "Carilah Tuhan saat menetapkan tujuan." ${ }^{41}$ Kehidupan dan pelayanan Tuhan Yesus adalah contoh yang sempurna. Alkitab mencatat "betapa besarnya tempat yang Yesus berikan kepada doa dalam hidup dan pekerjaan-Nya. Panggilan dan tugas yang dipercayakan Allah kepada-Nya sebagai utusan-Nya, Yesus terima dalam doa." ${ }^{2}$ Dalam Markus 1:35 mengatakan bahwa Pagi-pagi benar, waktu hari masih gelap, Ia bangun dan pergi ke luar. Ia pergi ke tempat yang sunyi dan berdoa di sana. Matius 14:23 mengatakan bahwa Dan setelah orang banyak itu disuruh-Nya pulang, Yesus naik ke atas bukit untuk berdoa seorang diri. Ketika hari sudah malam, Ia sendirian di situ.

Keempat, doa, tanda menyerahkan masalah kepada Tuhan. Masalah didalam pelayanan sangat bervariasi, mulai dari urusan yang berhubungan orang percaya dengan Tuhan, antar orang percaya, juga hidup orang percaya itu sendiri. Berbagai masalah tersebut bisa membuat orang percara mundur dari gereja bahkan murtad. Peran gembala yang berdoa sangat besar dalam menjaga jemaat bisa tetap bertahan, seperti yang R.C. Chapman lakukan: "Dia terus berdoa bagi orang yang tersinggung, menginginkan kembalinya seseorang ke dalam persekutuan. Di dalam penyelesaian

\footnotetext{
${ }^{40}$ Wilfried Stinissen Karmelit, Manusia: Siapakah Engkau? (Jogyakarta: Kanisius, 1983), 19.

${ }^{41}$ John Maxwell, A Leader's Heart, 156.

${ }^{42}$ Rick Warren, Pertumbuhan Gereja Masa Kini (Malang: Gandum Mas, 2003), 35.
} 
dosa dengan orang lain, dia sangat berhatihati." $" 43$

Dengan gembala berdoa untuk setiap masalah dalam jemaat, dia sedang menyerahkan masalah tersebut dan meminta Tuhan untuk memakai masalah bukan untuk menjauhkan dari-Nya tetapi membuat jemaat makin kuat didalan Tuhan. Itulah yang dilakukan hamba-Nya Epafras, "ia seorang dari antaramu, hamba Kristus Yesus, yang selalu bergumul dalam doanya untuk kamu, supaya kamu berdiri teguh, sebagai orang-orang yang dewasa dan yang berkeyakinan penuh dengan segala hal yang dikehendaki Allah." Kolose 4:12. Juga hamba-hamba Tuhan yang lain seperti rasul Paulus dan rasul Yohanes. Dalam 2 Tesalonika 1:11 mengatakan bahwa Karena itu kami senantiasa berdoa juga untuk kamu, supaya Allah kita menganggap kamu layak bagi panggilan-Nya dan dengan kekuatanNya menyempurnakan kehendakmu untuk berbuat baik dan menyempurnakan segala pekerjaan imanmu, Dalam 3 Yohanes 1:2 mengatakan bahwa Saudaraku yang kekasih, aku berdoa, semoga engkau baik-baik dan sehat-sehat saja dalam segala sesuatu, sama seperti jiwamu baik-baik saja.

Ketika gembala berdoa, maka Tuhan turun tangan untuk menyatakan pertolongannya. Torey berkata (seperti yang dikutip oleh Rick Warren) "doa adalah jalan yang ditujukan Allah untuk menerima sesuatu, "44 menerima segala hal yang menjadi kebutuhan jemaat. "Orang yang berdoa akan melihat kuasa Allah melalui doa tersebut." 45

Kelima, doa, tanda mau menyerahkan peperangan dalam pimpinan Tuhan. Dalam pelayanan, seorang gembala tidak hanya berurusan dengan orang percaya

${ }^{43}$ Robert L. Peterson dan Alexander Strauch, Kepemimpinan Agape (Yogyakarta: Andi, 1995), 56.

${ }^{44}$ Rick Warren, Pertumbuhan Gereja Masa Kini, 21.

${ }^{45}$ Jhon McArthur, Our Sufficiency In Christ (Dallas: Word Publishing, 1991), 118.

96 | Vol. 4 No. 2 (Desember 2020) (di alam nyata) dan permasalahannya, tetapi juga berurusan dengan roh-roh jahat di udara (alam roh) yang terus mencoba untuk mencuri, membunuh, bahkan membinasakan orang percaya. Yohanes 10:10. "Kehidupan Kristen adalah suatu peperangan"46 dan "peperangan sesungguhnya untuk pertumbuhan gereja yang efektif adalah secara rohani." 47 Dengan berdoa, gembala mengadakan perang atau penyerangan ke musuh yang tidak kelihatan. MD Wakkary memaparkan (seperti yang dikutip oleh Sularso Sopater), "menyembah dan doa adalah senjata peperangan rohani untuk mengalahkan iblis yang berusaha menghalangi pertumbuhan gereja.,

Dalam suatu kejadian, Tuhan Yesus didatangi oleh orang tua yang anaknya sakit ayan. Tuhan berkata bahwa "Jenis ini tidak dapat diusir kecuali dengan berdoa dan berpuasa. Mat 17:21 Ada jenis-jenis masalah yang tidak bisa diselesaikan melalui konseling ataupun dunia kedokteran tetapi melalui peperangan rohani walaupun kelihatannya hanya sebuah penyakit. Yang Tuhan lakukan adalah mengusir roh jahat yang menyebabkan anak itu sakit ayan.

Kisah yang lain dapat ditelusuri dalam peperangan Yoshua dan pasukan Israel melawan orang Amalek. Di kasus ini, kemenangan peperangan tidak ditentukan oleh seberapa kuat tentara dan seberapa banyak jumlah pasukannya, tetapi oleh doa Musa yang ditopang oleh Harun dan Hur. Dalam Keluaran 17:8-13 mengatakan bahwa Lalu datanglah orang Amalek dan berperang melawan orang Israel di Rafidim. Musa berkata kepada Yosua: "Pilihlah orang-orang bagi kita, lalu keluarlah berperang melawan orang Amalek, besok aku akan berdiri di puncak bukit itu dengan memegang tongkat Allah di tanganku." Lalu

\footnotetext{
${ }^{46}$ Mark R. Littleton, Siap Tempur (Bandung: Kalam Hidup, 1998), 17.

${ }^{47}$ C. Peter Wagner, Doa Peperangan (Jakarta: Metanoia, 1994), 38

${ }^{48}$ Sularso Sopater, dkk, Sebuah Bunga Rampai Pertumbuhan Gereja (Yogyakarta: Yayasan Andi), 34.
} 
Yosua melakukan seperti yang dikatakan Musa kepadanya dan berperang melawan orang Amalek; tetapi Musa, Harun dan Hur telah naik ke puncak bukit. Dan terjadilah, apabila Musa mengangkat tangannya, lebih kuatlah Israel, tetapi apabila ia menurunkan tangannya, lebih kuatlah Amalek. Maka penatlah tangan Musa, sebab itu mereka mengambil sebuah batu, diletakkanlah di bawahnya, supaya ia duduk di atasnya; Harun dan Hur menopang kedua belah tangannya, seorang di sisi yang satu, seorang di sisi yang lain, sehingga tangannya tidak bergerak sampai matahari terbenam. Demikianlah Yosua mengalahkan Amalek dan rakyatnya dengan mata pedang.

Contoh lainnya adalah kasus Daniel (Dan. 10:21). Ketika dia berdoa, maka segera Tuhan mengirim malaikat untuk memberi jawaban dari surga, tetapi di udara ada penguasa Persia (roh jahat yang menguasai negara Persia) yang menghalangi jawaban tersebut. Maka Daniel berdoa sampai 21 hari dan Tuhan mengirimkan malaikat lain untuk memerangi penguasa Persia, sedangkan pembawa jawaban doa dapat menemui Daniel. Dengan berdoa, gembala akan memenangkan berbagai peperangan dalam pelayanannya.

\section{Memiliki Hati yang Bergantung kepada Roh Kudus}

Kitab Kisah Para Rasul adalah sejarah para murid Tuhan melayani untuk pertama kalinya setelah Tuhan naik ke surga. sebelum naik ke surga, Tuhan berpesan untuk tidak pergi dulu sebelum diperlengkapi dengan kuasa dari atas, yaitu pribadi Roh Kudus. Kemudian mereka menunggu sambil berdoa dan terjadilah, mereka dibabtis oleh Roh Kudus. Sejak saat itu secara supra natural Roh Kudus menuntun mereka untuk melayani. Tuntuan Roh Kudus begitu nyata dialami oleh para rasul sendiri maupun jemaat.

Menurut penulis, lebih cocok kalau kitab para rasul disebut "Kisah Roh Kudus" karena Roh Kuduslah peran utama dalam banyak kisah pertobatan orang percaya, pelayanan hamba-hamba-Nya, dan pertumbuhan iman jemaat. Sebab itu "seorang pemimpin patut berdiam diri untuk mendengarkan masukan atau nasihat dari Firman Tuhan atau suara Roh Kudus"49 karena "Roh Kudus berperan besar dalam perkembangan pola hidup." ${ }^{50}$ Roh Kudus yang dinamis dan dapat menembus itu akan memandu pelayanan para pemimpin. AnugerahNya memampukan para pemimpin untuk melayani dalam kerendahatian dan kesederhanaan. Para pemimpin harus belajar untuk mendengarkan suara dan bergantung kepada Roh Kudus. Florence Bulle mengatakan, "Kita membutuhkan kearifan rohani yang berasal dari karunia Roh Kudus." Selain daripada itu, seorang pemimpin memerlukan apa yang disebut kedalaman spiritual. Ruang-ruang kosong di dalam jiwa seorang pemimpin haruslah diisi dengan Roh Kudus sehingga dia dapat melayani dengan kedalaman spiritual. ${ }^{52}$

Sekali lagi, Tuhan Yesus sendiri adalah teladan agung gembala dan gereja. Dia tidak akan melayani sebelum menerima babtisan Roh Kudus. Dalam Markus 1:1011 mengatakan bahwa pada saat Ia keluar dari air, Ia melihat langit terkoyak, dan Roh seperti burung merpati turun ke atas-Nya. Lalu terdengarlah suara dari sorga: "Engkaulah Anak-Ku yang Kukasihi, kepada-Mulah Aku berkenan."

Setelah menerima Roh Kudus dan diperkenan Bapa, maka sejak itulah Dia mulai melayani. Roh Kudud juga mulai bekerja didalam hidup-Nua, "Roh Kuduslah

\footnotetext{
${ }^{49}$ Daud Kurniawan, Kerajaan Allah di antara Kita (Bandung: Kalam Hidup, 2006), 81.

${ }^{50}$ Ibid., 256.

${ }^{51}$ Florence Bulle, Berbagai Tipuan dalam Pelayanan (Malang: Gandum Mas, 1997), 164.

${ }^{52}$ Frank Damazio, Pemimpin Barisan Depan: Sebuah Angkatan Baru Pemimpin Guna Menghadapi Masa Depan (Jakarta: Harvest Publication House, 1995), 12.
} 
yang membuat Yesus tampil berkarisma. Dari diriNya terpancar kekuatan pribadi yang membuat banyak orang percaya kepada-Nya. Bahkan Ia mampu membuat para pengikutNya meninggalkan segalagalanya guna mengikuti Dia dan berkarya bersama-sama dalam satu tim kerja yang padu dan konsisten."53

\section{Tugas Gembala sebagai Pendidik yang Mengajar Jemaat}

Tugas penggembalaan dengan jelas di sampaikan oleh Tuhan sendiri kepada Petrus khususnya dan kepada para gembala pada umumnya. Yohanes 21:15-17 Sesudah sarapan Yesus berkata kepada Simon Petrus: "Simon, anak Yohanes, apakah engkau mengasihi Aku lebih dari pada mereka ini?" Jawab Petrus kepada-Nya: "Benar Tuhan, Engkau tahu, bahwa aku mengasihi Engkau." Kata Yesus kepadanya: "Gembalakanlah domba-domba-Ku." Kata Yesus pula kepadanya untuk kedua kalinya: "Simon, anak Yohanes, apakah engkau mengasihi Aku?" Jawab Petrus kepada-Nya: "Benar Tuhan, Engkau tahu, bahwa aku mengasihi Engkau." Kata Yesus kepadanya: "Gembalakanlah domba-domba-Ku."

Kata Yesus kepadanya untuk ketiga kalinya: "Simon, anak Yohanes, apakah engkau mengasihi Aku?" Maka sedih hati Petrus karena Yesus berkata untuk ketiga kalinya: "Apakah engkau mengasihi Aku?" Dan ia berkata kepada-Nya: "Tuhan, Engkau tahu segala sesuatu, Engkau tahu, bahwa aku mengasihi Engkau." Kata Yesus kepadanya: "Gembalakanlah domba-domba$\mathrm{Ku}$.

Dalam Alkitab bahasa Yunani frase ini berbunyi, " $\pi$ o $\mu \alpha \mathrm{vv \varepsilon} \tau \alpha \quad \pi \rho \circ \beta \alpha \tau \alpha$

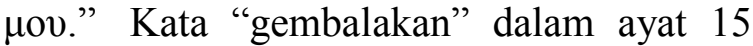
atau pertanyaan yang pertama menggunakan kata "boske" yaitu bentuk present impertif aktif dari kata 'boskoo' yang berarti "memberi makan." Sedangkan kata "gembalakan" dalam perintah kedua atau

${ }^{53}$ A.B. Susanto, Meneladani Jejak Yesus sebagai Pemimpin (Jakarta: PT Grasindo, 1997), 5. 98 | Vol. 4 No. 2 (Desember 2020) dalam ayat 16 ini menggunakan kata "poimaine, " bentuk present impertif aktif dari kata 'poimainoo' yang berarti "memberi makan, merawat atau memelihara kawanan domba." $" 54$

Dalam bahasa Inggris, kata "shepherd" (gembala) berakar dari kata "sheep" (domba). Tetapi dalam bahasa Ibrani kuno, kata "gembala" tidak berakar dari kata "domba", melainkan dari kata "memberi makan". Kata Ibrani untuk "gembala" ialah " $r a$ 'ah". Kata ini dibentuk dari kata "memberi makan". Akibatnya, gembala dikenal sebagai "orang yang memberi makan."55

Lebih luas lagi, tugas gembala sebagai pemimpin jemaat adalah: "(1). Mampu menyusun visi bagi masa depan, mampu menetapkan harapan yang tinggi, serta mampu memberikan perilaku yang mendukung pencapaian harapan yang tinggi tersebut. (2). Mampu untuk memberikan kekuatan kepada orang lain untuk menunjukkan kinerja yang baik dan terdorong untuk berprestasi, percaya diri dan terdorong untuk meraih kesuksesan. (3). Mampu untuk membangun relasi dengan orang lain melalui dukungan, empati, dan keyakinan akan kemampuan yang dimiliki orang lain." $" 56$

Dalam Perjanjian Baru, tugas gembala sebagai pemimpin jemaat, memakai istilah "penilik", Yun: Episkopos, bishop. Ing: overseer) yang terdapat dalam I Timotius 3:1; Filipi 1:1; Titus 1: 7a diartikan sebagai seorang pengawas, pimpinan, pelindung. Dalam bahasa Yunani kata ini adalah hasil gabungan dari dua kata, yaitu: "epi" yang berarti "melebihi", dan kata "skopos" yang berarti "melihat atau

\footnotetext{
${ }^{54}$ Wesley J. Perschbacher, The New Analytical Greek Lexicon (Grand Rapid: Hendrickson Publishers, 1998), 89.

${ }^{55}$ Oliver Mc Mahan, Gembala Jemaat yang Sukses, 5.

${ }^{56}$ Ernie Tisnawati Sule \& Kurniawan Saefullah, 255.
} 
mengamati”, memandang dengan tajam, mengawasi" $" 57$

Menurut Alexander Strauch: "In ancient Greek society, the word overseer (episkopos) was a well-known designation of office; it was broadly used to describe any official who acted as superintendent, manager, supervisor, guardian, controller, inspector, or ruler. "58

Tugas penggembalaan secara umum adalah menjadi "seorang pandu. Dombadomba tidak dapat jalan sendiri. Mereka memperlukan pimpinan manusia. Mereka tidak dapat pergi sendiri ketempat yang sudah di tentukan terlebih dahulu. Mereka mengetahui bahwa gembala itulah pandu mereka, mereka merasa aman untuk pengikutnya. Gembala tidak dapat menggiring domba-domba-Nya, ia harus memimpin mereka." ${ }^{59}$

Dari beberapa sumber diatas, penulis simpulkan bahwa tugas gembala adalah (1). memberi makan, (2). memelihara dan (3). memimpin kawanan domba. Ketiga tugas hal tersebut menurut Harianto GP bahwa penggembalaan sebagai wujud dari pemeliharaan iman. Iman menjadi sasaran utama untuk dipelihara sehingga iman itu menjadi hidup. Iman itu berfokus kepada Ysus Kristus: iman seperti Yesus. Dengan demikian, manusia yang menerima Yesus sebagai Juruselamatnya adalah manusia yang beriman dalam Yesus. Allah mengajarkan agar iman Yesus itu jangan sampai "padam" dan terus hidup menyalanyala dalam hati jemaat. Iman yang hidup akan membuahkan hal-hal yang manusia sendiri tidak sanggup menjalankannya adalah kehidupan yang penuh dengan

\footnotetext{
${ }^{57}$ Kevin J. Conner, Jemaat dalam Perjanjian Baru (Malang: Gandum Mas, 2004), 239.

${ }^{58}$ Alexander Strauch, The New Testament Deacon (Colorado: Lewis and Roth Publishers, 1997), 59.

${ }^{59}$ Charles Jefferson, Pejabat Gereja sebagai Gembala Sidang (Nederland: Mimery Press, 1977), 47-48.
}

mukjizat Allah. Kuasa Allah hidup bersama diri seseorang yang mempunyai iman yang hidup. Biakan iman dalam Yesus terus hidup, hidup, dan selalu hidup. ${ }^{60}$

\section{Memberi Makan}

Memberi makan dalam konteks penggembalaan jemaat adalah berbicara tentang mengajar firman kebenaran dan mendidik mereka melakukannya. Menu makanan yang sehat adalah dari dalam kitab suci sendiri seperti yang Paulus sampaikan kepada Timotius. Dalam 1 Timotius 6:2b-5 Ajarkanlah dan nasihatkanlah semuanya ini. Jika seorang mengajarkan ajaran lain dan tidak menurut perkataan sehat-yakni perkataan Tuhan kita Yesus Kristus-dan tidak menurut ajaran yang sesuai dengan ibadah kita, ia adalah seorang yang berlagak tahu padahal tidak tahu apa-apa. Penyakitnya ialah mencari-cari soal dan bersilat kata, yang menyebabkan dengki, cidera, fitnah, curiga, percekcokan antara orang-orang yang tidak lagi berpikiran sehat dan yang kehilangan kebenaran, yang mengira ibadah itu adalah suatu sumber keuntungan.

Ajaran yang sehat itu seperti makanan yang sehat. Ajaran sehat itu akan membuat rohani jemaat sehat seperti, makin mengerti arti kasih Tuhan, percaya Tuhan dalam segala keadaan, dsb. Itulah yang Paulus sebut mendatang keuntungan bagi jemaat. Sebaliknya kalau ajaran yang disampaikan tidak sehat, maka akibatnya akan menimbulkan percecokan, saling curiga, dan sebagainya. Oleh sebab itu "tugas utama dan prinsip dari seorang Gembala adalah memberi makan kepada domba-dombanya dengan khotbah yang dalam dari Alkitab" 61 dan "harus selalu menempatkan Firman Allah di depan kita sebagai aturan hidup, dan tidak

\footnotetext{
${ }^{60}$ Harianto GP, Teologi Pastoral (Yogyakarta: Andi, 2019), 70.

${ }^{61}$ The Works of John Owen, ed. William H. Goold (London: Banner of Truth Trust, 1965), 16:74.
} 
mempercayai yang lain selain apa yang diajarkan Alkitab, tidak mengasihi yang lain selain yang ditentukan Alkitab, tidak membenci yang lain selain yang dibenci Alkitab, tidak melakukan yang lain selain yang diperintahkan oleh Alkitab.,"62 "Khotbah tidak boleh memutarbalikan Kitab Suci, namun secara literal harus dari dalam Alkitab; bukan teks di dalam khotbah, namun khotbah di dalam teks. ${ }^{63}$

Prinsip dasar dari ajaran yang sehat itu adalah hanya dari firman Tuhan dalam pengertian sebagai dasar atau menu utama, sedangkan untuk menu tambahan, bisa memakai menu lain selama hal itu masih pararel dengan firman Tuhan. Banyak pengetahuan diluar kitab suci yang mendukung dan mengkonfirmasi kebenaran kitab suci seperti bidang kesehatan, psikologi, dan komputer. Ralph M. Riggs mengatakan, bahwa pelayanan seorang pendeta (gembala jemaat) meliputi tugastugas dan tujuan tertentu. Yang paling utama adalah memberitakan firman. Allah telah menetapkan bahwa dengan kebodohan pemberitaan Injil, manusia akan diselamatkan (1 Korintus 1:21). ${ }^{64}$ Tugas utama seorang gembala adalah memberitakan Injil.

Menurut Peter C. Wagner dalam bukunya Manfaat Karunia Roh, "pemberitaan Injil adalah alat utama bagi pertumbuhan." 65 Kalimat "pemberitaan injil" memiliki dua pengertian yang saling memperlengkapi. Pertama, dalam arti sempit, memberitakan jalan keselamatan melalui pengorbanan Tuhan kita. Kedua, dalam arti luas, memberitakan berbagai kebenaran kitab suci juga merupakan pemberitaan injil. Dua pengertian diatas

\footnotetext{
62،Food for New-Born Babes,"

in The Works of Henry Smith, ed. Thomas Smith (Edinburgh: James Nichol, 1866), 1: 494.

${ }^{63}$ The Paul's Cross Sermons, 1534-1642

(Toronto: University of Toronto Press, 1958), 165.

${ }^{64}$ Ralph M. Riggs, Gembala Sidang yang Berhasil (Malang: Gandum Mas, 1996), 71.

${ }^{65}$ Peter Wagner, Manfaat Karunia Roh (Malang: Gandum Mas, 2010), 173. 100 | Vol. 4 No. 2 (Desember 2020)
}

masih dalam konteks tugas gembala yang memberi makan dunia atau dan jemaat.

Pekerjaan gembala dalam memberi makan domba-dombanya juga merupakan salah satu dari 3 aspek pelayanan gereja, yaitu "melayani orang-orang kudus (Efesus 4:12-16)" "66 seperti yang diuraikan oleh E. P. Clowney dalam "New Dictionary of Theology." Sedangkan menurut Henry C Thiessen dalam membahas tentang misi gereja ia mengemukakan 7 aspek misi gereja, khususnya aspek ke 4, yaitu "mendidik anggotanya dalam kebenaran (to educate its constituency),"67 juga bagian dari arti memberi makan jemaat.

\section{Memelihara}

Bentuk pemeliharan jemaat dalam konteks pelayanan adalah pemeliharan pribadi, kelompok kecil dan kelompok besar. Pemeliharaan pribadi berbicara tentang pelayanan konseling gembala kepada jemaat yang memerlukan arahan dari pemimpin untuk masalah-masalah pribadi mereka. Sedangkan pemeliharaan bersamasama dalam kelompok kecil adalah pengelompokan jemaat dalam kelompokkelompok kecil untuk memberi kesempatan sesama jemaat untuk saling mengajar dan membangun satu sama lain. disisi yang lain adalah pemeliharaan dalam kelompok besar seperti berbagai macam ibadah untuk kepentingan yang umum.

Pemeliharaan ini merupakan langkah lanjutan yaitu memberi pelayanan pendampingan kepada jemaat untuk belajar mempraktekan kebenaran firman Tuhan dalam hidup mereka berikut:

Pertama, pemeliharaan pribadi. Pemeliharaan gembala sebagai pemimpin jemaat haruslah dalam berbagai bentuk mengingat bahwa setiap orang percaya adalah pribadi yang unik, disisi yang lain orang-orang percaya juga sebuah kumpulan yang heterogen, terdiri dari berbagai macam latarbelakang, suku, dan budaya yang

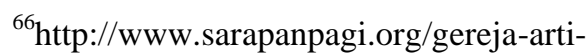
dan-perannya-vt6452.html.

${ }^{67}$ Ibid.
} 
berbeda. Nasehat C.H. Spurgeon untuk para gembala adalah, "Carilah domba yang tersesat satu per satu, jangan membenci pekerjaan Anda ini, karena Tuhan Anda dalam perumpamaan-Nya menceritakan gembala yang baik selalu memperhatikan dombanya, bukan dalam suatu kawanan, namun satu per satu.",68

Richard Baxter juga menasehatkan kepada para gembala, "Para pelayan tidak hanya melulu menjadi pengkhotbah publik, namun juga dikenal sebagai konselor bagi jiwa-jiwa mereka, sebagai dokter untuk tubuh mereka."69 Dua aspek pemeliharaan jemaat juga ditekankan oleh Richard Baxter, yaitu mengajar jemaat secara pribadi dan mengajar jemaat secara bersama-sama. selanjutnya, diuraikan kegunaan dari mengajar secara pribadi sebagai bentuk pemeliharaan adalah "memahami dengan natur anugerah yang menyelamatkan, dan dapat membantu mereka menguji keadaannya, dan memecahkan pertanyaan utama berhubungan dengan kehidupan atau kematian kekal mereka. Satu perkataan yang dapat dipertanggungjawabkan, nasehat yang bijaksana, yang diberikan oleh hamba Tuhan kepada orang-orang yang membutuhkan, mungkin lebih berguna dari pada banyak khotbah., 70

Pemeliharaan pribadi sangat dibutuhkan jemaat mengingat bahwa setiap kebenaran yang awalnya merupakan pengetahuan, memerlukan pendampingan untuk mulai menerapkan dan akhirnya menjadikannya trampil.

Pola yang sama juga terjadi misalnya dalam dunia olahraga, yaitu badminton. Seseorang yang tahu teori memukul bola backhand, tidak secara otomatis bisa menerapkannya. Perlu coaching untuk

${ }^{68} \mathrm{C}$. H. $\quad$ Spurgeon, Lectures to $\quad M y$ Students (New York: Robert Carter \& Brothers, 1889), 60-61.

${ }^{69}$ Richard Baxter, The Reformed Pastor (Edinburgh, Scotland: Banner of Truth Trust, 1989, reprinted from the 1656 edition), 94-97.

${ }^{70}$ Ibid. memberi contoh, menuntun step by step hingga bisa. Selama dalam rangka mempraktekkan teori tersebut, pelatih tetap memantau untuk melihat apakah ada kesalahan atau sebaliknya sudah mulai bagus. Kalau sudah bagus, maka pelatih akan mengajarkan teori yang lain, begitu seterusnya.

Kedua, pemeliharaan bersama-sama dalam kelompok kecil. Kata "kelompok kecil" dalam bahasa Inggris dipakai kata group. $^{71}$ Sedangkan dalam bahasa Indonesia, berarti: kelompok; golongan, atau golongan-golongan yang membagi-bagi atas kelompok-kelompok. ${ }^{72}$

Dalam melayani jemaat, pengelompokan dalam jumlah kecil sangat efektif untuk membagi tugas perhatian kepada orang -orang yang sanggup dipercayai. Apalagi kalau pengelompokkannya berdasarkan homogenitas, seperti sesama level pendidikan (kelompok pelajar SMU, kelompok mahasiswa), atau sesama gender (kelompok kaum pria, kelompok kaum wanita), atau sesama jenis pekerjaan (kelompok profesional, kelompok pengusaha).

Dalam Perjanjian Lama, salah satu pencetus ide kelompok kecil ini adalah Yitro, mertua Musa. Yitro menyampaikan ide kecil ini karena melihat bagaimana Musa tiap hari melayani umat Israel seorang diri mulai dari pagi sampai sore (Kel. 18:13). Ketika Mertua Musa melihat hal ini, Dia berkata "Tidak baik seperti yang kaulakukan itu. Exo 18:18 Engkau akan menjadi sangat lelah, baik engkau baik bangsa yang beserta engkau ini; sebab pekerjaan ini terlalu berat bagimu, takkan sanggup engkau melakukannya seorang diri saja" (Kel. 18:17-18). "Kemudian Yitro memberi

\footnotetext{
${ }^{71}$ John M. Echols dan Hassan Shadily, Kamus Inggris-Indonesia (Jakarta: PT. Gramedia, 1996), 281.

${ }^{72}$ Hasan Alwi, dkk, Kamus Besar Bahasa Indonesia, 201.
} 
nasehat kepada Musa. Sesuai dengan nasihat Yitro, Musa memilih orang-orang bertalenta, mengangkat mereka menjadi pemimpin atas 1000 orang, 100 orang, 50 orang, dan 10 orang." 73 "Musa membagibagi bangsa Israel menjadi kelompokkelompok kecil, untuk memungkinkan setiap orang menerima perhatian yang lebih baik."74

Dalam Keluaran 18:21-22 Di samping itu kaucarilah dari seluruh bangsa itu orang-orang yang cakap dan takut akan Allah, orang-orang yang dapat dipercaya, dan yang benci kepada pengejaran suap; tempatkanlah mereka di antara bangsa itu menjadi pemimpin seribu orang, pemimpin seratus orang, pemimpin lima puluh orang dan pemimpin sepuluh orang. Dan sewaktuwaktu mereka harus mengadili di antara bangsa; maka segala perkara yang besar haruslah dihadapkan mereka kepadamu, tetapi segala perkara yang kecil diadili mereka sendiri; dengan demikian mereka meringankan pekerjaanmu, dan mereka bersama-sama dengan engkau turut menanggungnya.

Yitro melihat bahwa hasil dari pembagian kelompok kecil ini adalah kepuasan baik pemimpin maupun jemaat. Yitro berkata: "Jika engkau berbuat demikian dan Allah memerintahkan hal itu kepadamu, maka engkau akan sanggup menahannya, dan seluruh bangsa ini akan pulang dengan puas senang ke tempatnya."

Dalam Perjanjian Baru, ada indikasi yang kuat kalau jemaat selain beribadah dalam kelompok yang besar, "mereka juga mengadakan pertemuan ibadah di rumahrumah. ${ }^{75}$ Pertemuan tersebut dipakai untuk memelihara rohani mereka dengan mengajar dan memberitakan kebenaran tentang Yesus sebagai Mesias (Kis. 5:42).

\footnotetext{
${ }^{73}$ Mary Go, Dinamika Kelompok (Malang: Seminari Alkitab Asia Tenggara, 1994), 22.

${ }^{74}$ Steven Barker, dkk, Buku Pegangan Pemimpin Kelompok Sel (Jakarta: Perkantas, 2000), 14.

${ }^{75}$ Obaja Tanto Setiawan, Kelompok Kecil Prisip 12 (Solo: Departemen Media GBI Keluarga Allah, 2000), 27.
}

102 | Vol. 4 No. 2 (Desember 2020)
Jadi kelompok sel, adalah sebagai tempat mempraktekkan gaya hidup Allah, tempat Allah menyatakan diri kepada umatNya dan sebagai tempat Allah melipatgandakan gaya hidup-Nya, ${ }^{76}$ seperti berkumpul untuk "bertekun dalam pengajaran rasul-rasul dan dalam persekutuan. Dan mereka selalu berkumpul untuk memecahkan roti dan berdoa (Kis. 2:42)." Kelompok kecil juga merupakan tempat untuk saling menasehati, yaitu mengajar dan memberi contoh bagaimana seharusnya hidup sebagai umat-Nya.

Dalam perkembangan selanjutnya, "pada akhir abad-18, Allah telah mengerakkan John Wesley untuk bergerak dalam penginjilan dan pemuridan di dalam kelompok. Wesley telah berhasil mengembangkan lebih dari 10.000 kelompok yang disebut dengan kelas. Dengan demikian, maka John Wesley merupakan pendahulu dari kegerakan sel modern. Ratusan ribu orang ikut serta di dalam sistem kelompok-kelompok kecil yang dipelopori oleh Wesley tersebut. Kelas-kelas tersebut, berfungsi sebagai alat penginjilan dan agen pemuridan." 77

Ketiga, pemeliharaan bersama dalam kelompok besar atau. Ibadah dan mengajar jemaat dalam ibadah umum, kaum bapak, kaum ibu, pemuda, remaja. Anak, profesional, dan persekutuan lainnya.

\section{Memimpin}

Tugas yang lain dari pemimpin jemaat selain memberi makan dan memelihara adalah memimpin, dan dalam konteks penggembalaan, memimpin berarti mengarahkan jemaat yang sudah tahu firman kebenaran dan yang sudah belajar mempraktekkannya, menjadi jemaat yang holistik. Gembala membimbing jemaat untuk hidup dalam tujuannya Tuhan yang lebih lagi.

\footnotetext{
${ }^{76}$ Eddy Leo, Panduan Membangun Esensi dan Substansi Komunitas Sel (Jakarta: Yayasan Media Buana Indonesia, 2002), iv.

${ }^{77}$ Joel Comiskey, Ledakan Kelompok Sel (Jakarta: Metanoia, 1998), 25.
} 
Kata 'holistik' berasal dari kata "whole' (Inggris) yang artinya: seluruhnya, sepenuhnya. "Whole" berarti (1) Containing all component parts; complete. (2) Not divided or disjoined; in one unit. (3) Constituting the full amount, extent, or duration. ${ }^{78}$ Dalam konteks gereja, kata holistik mencakup empat jenis tugas yang saling memperlengkapi satu sama lain, yaitu "(1). Menyembah (Yunani, Latreia), (2). Persekutuan (Yunani, Koinonia), (3). Pelayanan (Yunani, Diakonia), (4). Kesaksian (Yunani, Marturia)."79

Kalau dibuat dalam dua kelompok besar, maka tugas Gembala sebagai pemimpin jemaat adalah memimpin jemaat untuk saling melayani di komunitas antar orang percaya, dan melayani Dunia. Dalam konteks saling melayani dalam sebuah gereja lokal, "Gereja sebagai tubuh Kristus merupakan wadah dari berbagai golongan usia, gereja tidak hanya berpatokan pada satu usia saja, gereja tidak hanya berpatokan pada satu sisi saja, misalnya hanya memperhatikan ibadah umum dan mengabaikan ibadah yang terbagi menurut usia (seperti sekolah minggu, ibadah pemuda, ibadah kaum wanita dan sebagainya). Keberhasilan dari pelayanan gereja bila tiap kegiatan yang ada dapat berkolaburasi dan menghasilkan jemaat yang taat akan Firman Tuhan". ${ }^{80}$ Adanya pelayanan khusus (kategorial) ini adalah karena melibatkan warga yang mempunyai kesamaan minat dalam bidang-bidang tertentu seperti kewanitaan, kepemudaan,

\footnotetext{
${ }^{78}$ John M. Echols dan Hasan Shadily, Kamus Inggris Indonesia (Jakarta: Gramedia Pustaka Utama), 646.

${ }^{79}$ http://www.sarapanpagi.org/gereja-artidan-perannya-vt6452.html.

${ }^{80}$ Johni Hardori, (2000), "Mingguan Berita Umum Jemaat Indonesia", Suara Jemaat Indonesia, No. 88.
}

pendidikan anak-anak dan remaja, kebapaan. ${ }^{81}$

Sisi yang lain adalah gembala "harus memperlengkapi jemaatnya agar melaksanakan keseluruhan agenda Allah, yakni membawa "seluruh ciptaan" di bawah ke-Tuhanan Kristus. ... Gereja harus memperlengkapi dan mendorong jemaatnya untuk memberi pengaruh di tempat mereka sendiri dan selaras dengan tujuan besar Allah di dunia, yaitu memulihkan segala sesuatu. Ketika gereja memuridkan dengan pemahaman "segala sesuatu", hal itu akan melengkapi jemaatnya untuk membawa lingkungan yang mereka pengaruhi di bawah keTuhanan Kristus berikut: ${ }^{82}$ (1) memimpin jemaat untuk melayani berbagai bidang dan (2) mempimpin jemaat untuk mendukung pendidikan di luar gereja: mendukung keuangan pendidikan, menyediakan guru agama, mendirikan sekolah.

\section{Yesus sebagai Model Gembala Sejati dan relasinya terhadap Gembala sebagai Pendidik}

Dalam kitab suci, profil Tuhan sebagai gembala diuraikan dengan jelas dan sangat luas. Dengan mempelajari penggembalaan-Nya kepada umat Israel, para gembala yang memimpin jemaat bisa meneladani jejak-Nya. Perjanjian Lama, "berulang-ulang melukiskan Allah sebagai gembala Israel. (Kej. 49:24; Mzm. 23:1; 80:2), lemah lembut dalam pengasuhan-Nya (Yes. 40:11), tapi kadang-kadang membina kawanan domba-Nya, dengan kemarahanNya kemudian dengan pengampunan-Nya kembali (Yer. 31:10)." ${ }^{, 83}$ Khususnya dalam Mazmur 23, melalui pewahyuan yang di

${ }^{81}$ O. E. Ch. Wuwungan, Bina Warga; Bunga Rampai Pembinaan Warga Gereja (Jakarta: BPK Gunung Mulia, 2012), 127.

${ }^{82}$ Bob Moffitt dan Karla Tesch, Andaikan Yesus Kepala Daerah: Transformasi dan Gereja Lokal (Jakarta: Yayasan Komunikasi Bina Kasih, 2010), 91.

${ }^{83}$ J. D Douglas, Ensiklopedi Alkitab Masa Kini Jilid 1 A-L, 330-331. 
berikan kepada raja Daud, Tuhan secara detail menggambarkan siapa diri-Nya dan yang dikerjakan-Nya sebagai Gembala Agung.

Mazmur 23:1-6 mengambarkan bahwa TUHAN adalah gembalaku, takkan kekurangan aku. Ia membaringkan aku di padang yang berumput hijau, Ia membimbing aku ke air yang tenang; Ia menyegarkan jiwaku. Ia menuntun aku di jalan yang benar oleh karena nama-Nya. Sekalipun aku berjalan dalam lembah kekelaman, aku tidak takut bahaya, sebab Engkau besertaku; gada-Mu dan tongkat$\mathrm{Mu}$, itulah yang menghibur aku. Engkau menyediakan hidangan bagiku, di hadapan lawanku; Engkau mengurapi kepalaku dengan minyak; pialaku penuh melimpah. Kebajikan dan kemurahan belaka akan mengikuti aku, seumur hidupku; dan aku akan diam dalam rumah TUHAN sepanjang masa. Dari Mazmur 23:1-6 yang Tuhan kerjakan sebagai Gembala Agung umat-Nya adalah: (1) Membaringkan umat-Nya di padang yang berumput hijau, Membimbing umat-Nya ke air yang tenang, (3) Menyegarkan jiwa umat-Nya, (4) Menuntun umat-Nya di jalan yang benar oleh karena nama-Nya, (5) Beserta umatNya; gada-Nya dan tongkat-Nya, (6) Menyediakan hidangan bagi umat-Nya, di hadapan lawanku, dan (7) Mengurapi kepala umat-Nya dengan minyak; piala domba penuh melimpah.

Sedangkan Perjanjian Baru, Tuhan Yesus menggambarkan diri-Nya sebagai gembala yang "kuat, rela berkorban, dan tidak mementingkan diri sendiri (Yoh. 10:11-15). ${ }^{84}$ "Gembala yang baik juga haruslah mengasihi semua orang, Yesus juga mengatakan bahwa gembala yang baik menyerahkan nyawanya demi keselamatan domba-dombanya. Selain dari pada itu, gembala yang baik harus berani dan tekun. Menurut Tuhan gembala yang baik ialah bergairah untuk mengasihi, mempunyai beban dan tidak mementingkan diri

\footnotetext{
${ }^{84}$ Mang Ucup, Hamba Duit VS Hamba Allah (Yogyakarta: Kairos, 2005), 116-117. 104 | Vol. 4 No. 2 (Desember 2020)
}

sendiri. $^{85}$ Dalam Yohanes 10:11-16 mengatakan bahwa Akulah gembala yang baik. Gembala yang baik memberikan nyawanya bagi domba-dombanya; sedangkan seorang upahan yang bukan gembala, dan yang bukan pemilik dombadomba itu sendiri, ketika melihat serigala datang, meninggalkan domba-domba itu lalu lari, sehingga serigala itu menerkam dan mencerai-beraikan domba-domba itu. Ia lari karena ia seorang upahan dan tidak memperhatikan domba-domba itu. Akulah gembala yang baik dan Aku mengenal domba-domba-Ku dan domba-domba-Ku mengenal Aku sama seperti Bapa mengenal Aku dan Aku mengenal Bapa, dan Aku memberikan nyawa-Ku bagi domba-domba$\mathrm{Ku}$. Ada lagi pada-Ku domba-domba lain, yang bukan dari kandang ini; domba-domba itu harus Kutuntun juga dan mereka akan mendengarkan suara-Ku dan mereka akan menjadi satu kawanan dengan satu gembala.

Dari Yohanes 10:11-16 yang Tuhan kerjakan sebagai Gembala Agung umat-Nya adalah: (1) Memberikan nyawanya bagi Umat-Nya, (2) Memperhatikan Umat-Nya, (3) Mengenal Umat-Nya, (4) Memberikan nyawa-Ku bagi domba-domba-Ku, dan (5) Menuntun juga Umat yang lain walaupun bukan dari kandang.

Gambaran Yesus sebagai model gembala digunakan sebagai sarana materi proses belajar mengajar baik terhadap dirinya sebagai pendidik mapun terhadap jemaatnya agar baik pendidik maupun jemaat terjadi perubahan sesuai dengan karakteristik gembala sejati adalah Yesus Kristus. Gembala dan jemaatnya mempunya gaya hidup seperti Kristus. Gambaran model Yesus sebagai gembala adalah: membaringkan umat-Nya di padang yang berumput hijau, (2) membimbing umat-Nya ke air yang tenang, (3) menyegarkan jiwa umat-Nya, (4) menuntun umat-Nya di jalan yang benar oleh karena nama-Nya, (5) beserta umat-Nya; gada-Nya dan tongkat-

\footnotetext{
${ }^{85}$ Robert Cowles, Gembala Sidang (Bandung: Yayasan Kalam Hidup 2000), 710.
} 
Nya, (6) menyediakan hidangan bagi umatNya, di hadapan lawanku, (7) mengurapi kepala umat-Nya dengan minyak; piala domba penuh melimpah, (8) memberikan nyawanya bagi Umat-Nya, memperhatikan Umat-Nya, (10) mengenal Umat-Nya, (11) memberikan nyawa-Ku bagi domba-domba-Ku, dan (12) menuntun juga Umat yang lain walaupun bukan dari kandang.

Gembala wajib hidup seperti teladan Yesus. Yesus memberikan teladan bagaimana menjadi seorang gembala yang baik di mana gembala yang baik adalah gembala yang merawat atau memelihara kawanan domba dengan sepenuh hati bahkan rela mengorbankan nyawanya demi domba-dombanya (Yoh. 10:11). Tugas penggembalaan adalah tugas yang dipercayakan oleh Allah untuk dilaksanakan sesuai dengan petunjuk dan ketetapan dari Allah sendiri. Dalam 1 Petrus 5:1-4, dijelaskan tentang ciri khas dari gembala sidang yang membedakannya dengan pemimpin pada umumnya. Ciri khas tersebut harus menjiwai pelayanan seorang gembala sidang dalam melaksanakan tugas penggembalaan. Seorang gembala sidang harus melayani dengan sukarela, pengabdian diri, rendah hati dan mampu menjadi teladan yang baik. ${ }^{86}$

\section{KESIMPULAN}

Kepribadian Gembala jemaat adalah seseorang yang pekerjaannya menjaga, memelihara, memberi makan dan yang memiliki hubungan dengan orang-orang yang dilayaninya. Gembala harus memperhatikan bagaimana membangun diri sendiri, memperhatikan karakternya sendiri sebelum memperhatikan karakter orang lain, dan gembala harus berani menasehati

\footnotetext{
${ }^{86}$ Calvin Sholla Rupa, (2016), "Ciri Khas Seorang Gembala berdasarkan Perspektif 1 Petrus 5: 1-4”, Jurnal Jaffray, 14(2), 165-168.
}

dirinya sendiri sebelum menasehati orang lain. Gembala mempunyai mempunyai karakteristik adalah: memiliki hati yang melayani, memiliki integritas, memiliki waktu pribadi untuk berdoa, dan memiliki hati yang bergantung kepada Roh Kudus.

Tugas gembala sebagai pendidikan yang mengajar jemaat adalah: (1) memberi makan, dalam arti: makan dalam konteks penggembalaan jemaat adalah berbicara tentang mengajar firman kebenaran dan mendidik mereka melakukannya. Menu makanan yang sehat adalah dari dalam kitab suci sendiri seperti yang Paulus sampaikan kepada Timotius. (2) memelihara, dalam arti: bentuk pemeliharan jemaat dalam konteks pelayanan adalah pemeliharan pribadi, kelompok kecil dan kelompok besar. (3) dan memimpin, dalam arti: (a) memimpin jemaat untuk melayani berbagai bidang dan (b) mempimpin jemaat untuk mendukung pendidikan di luar gereja: mendukung keuangan pendidikan, menyediakan guru agama, mendirikan sekolah.

Gambaran Yesus sebagai model gembala digunakan sebagai sarana materi proses belajar mengajar baik terhadap dirinya sebagai pendidik mapun terhadap jemaatnya agar baik pendidik maupun jemaat terjadi perubahan sesuai dengan karakteristik gembala sejati adalah Yesus Kristus. Gembala dan jemaatnya mempunya gaya hidup seperti Kristus. Gambaran model Yesus sebagai gembala adalah: (1) membaringkan umat-Nya di padang yang berumput hijau, (2) membimbing umat-Nya ke air yang tenang, (3) menyegarkan jiwa umat-Nya, (4) menuntun umat-Nya di jalan yang benar oleh karena nama-Nya, (5) beserta umat-Nya; gada-Nya dan tongkatNya, (6) menyediakan hidangan bagi umatNya, di hadapan lawanku, (7) mengurapi kepala umat-Nya dengan minyak; piala domba penuh melimpah, (8) memberikan nyawanya bagi Umat-Nya, (9) memperhatikan Umat-Nya, (10) mengenal 
Umat-Nya, (11) memberikan nyawa-Ku bagi domba-domba-Ku, dan (12) menuntun juga Umat yang lain walaupun bukan dari kandang.

\section{DAFTAR PUSTAKA}

"Food for New-Born Babes," in The Works of Henry Smith, ed. Thomas Smith. Edinburgh: James Nichol, 1866.

"gembala", Kamus Besar Bahasa Indonesia. CD-ROM. Offline. Versi 1.5.1.

Barker, Steven dkk. Buku Pegangan Pemimpin Kelompok Sel. Jakarta: Perkantas, 2000.

Baxter, Richard. The Reformed Pastor. Edinburgh, Scotland: Banner of Truth Trust, 1989.

Bulle, Florence. Berbagai Tipuan dalam Pelayanan. Malang: Gandum Mas, 1997.

Chandra, Robby. Landasan Pacu Kepemimpinan. Yogyakarta: Gloria Graffa, 2005.

Comiskey, Joel. Ledakan Kelompok Sel. Jakarta: Metanoia, 1998.

Conner, Kevin J. Jemaat dalam Perjanjian Baru. Malang: Gandum Mas, 2004.

Cowles, Robert. Gembala Sidang. Bandung: Yayasan Kalam Hidup 2000.

Damazio, Frank. Pemimpin Barisan Depan: Sebuah Angkatan Baru Pemimpin Guna Menghadapi Masa Depan. Jakarta: Harvest Publication House, 1995.

Darmaputera, Eka. Kepemimpinan dalam Perspektif Alkitab. Yogyakarta: Kairos, 2005.

Dennis, Jay. Eksperimen Doa. Jakarta: Immanuel, 2002.

Douglas, J. D. Ensiklopedi Alkitab Masa Kini Jilid 1 A-L. Jakarta: Yayasan Komunikasi Bina Kasih/OMF, 2002.

Echols, John M. dan Shadily, Hassan. Kamus Inggris-Indonesia. Jakarta: PT. Gramedia, 1996.
Foster, Richard J. Tertib Doa. Malang: Gandum Mas, 1990.

Go, Mary. Dinamika Kelompok. Malang: Seminari Alkitab Asia Tenggara, 1994.

GP, Harianto. Teologi Pastoral. Yogyakarta: Andi, 2019.

Hardori, Johni. (2000), "Mingguan Berita Umum Jemaat Indonesia", Suara Jemaat Indonesia, No. 88.

http://kamusbahasaindonesia.org/integritas. http://kbbi.web.id/gembala.

http://kingdomcommunication.blogspot.co.i d/2008_03_01_archive.html.

http://www.merriamwebster.com/dictionary/integrity.

http://www.sarapanpagi.org/gereja-arti-danperannya-vt6452.html.

Jefferson, Charles. Pejabat Gereja sebagai Gembala Sidang. Nederland: Mimery Press, 1977.

Karmelit, Wilfried Stinissen. Manusia: Siapakah Engkau? Yogyakarta: Kanisius, 1983.

Kurniawan, Daud. Kerajaan Allah di antara Kita. Bandung: Kalam Hidup, 2006.

Lamb, Jonathan. Integritas. Jakarta: Perkantas, 2008.

Leo, Eddy. Panduan Membangun Esensi dan Substansi Komunitas Sel. Jakarta: Yayasan Media Buana Indonesia, 2002.

Littleton, Mark R. Siap Tempur. Bandung: Kalam Hidup, 1998.

Mahan, Oliver Mc. Gembala Jemaat yang Sukses. Jakarta: Sinode GBI Jakarta, 2002.

Mahoney, Ralph. Pembentukan Seorang Pemimpin. Glenoaks, Burbank, USA: World Missionary Assistance Plan, tp.t.

Maxwell, John C. Mengembangkan Kepemimpinan di dalam Diri Anda. Jakarta: Binarupa Aksara,1995.

Maxwell, John. A Leader's Heart. Bandung: Pionir Jaya, 2011.

McArthur, Jhon. Our Sufficiency In Christ. Dallas: Word Publishing, 1991. 
Moffitt, Bob dan Tesch, Karla. Andaikan Yesus Kepala Daerah: Transformasi dan Gereja Lokal. Jakarta: Yayasan Komunikasi Bina Kasih, 2010.

Perchbacher, Wesley J. The New Analytical Greek Lexicon. Grand Rapid: Hendrickson Publishers, 1998.

Peterson, Robert L. dan Strauch, Alexander. Kepemimpinan Agape. Yogyakarta: Andi, 1995.

Riggs, Ralph M. Gembala Sidang yang Berhasil. Malang: Gandum Mas, 1996.

Rupa, Calvin Sholla. (2016), "Ciri Khas Seorang Gembala berdasarkan Perspektif 1 Petrus 5: 1-4", Jurnal Jaffray, 14(2), 165-168.

Sendjaya. Kepemimpinan Kristen. Yogyakarta: Kairos, 2004.

Senduk, H.L. Pelayan Tuhan. Jakarta: Yayasan Bethel, 2010.

Setiawan, Obaja Tanto. Kelompok Kecil Prinsip 12. Solo: Departemen Media GBI Keluarga Allah, 2000.

Sopater, Sularso dkk. Sebuah Bunga Rampai Pertumbuhan Gereja. Yogyakarta: Yayasan Andi, 2010.

Spurgeon, C. H. Lectures to My Students. New York: Robert Carter \& Brothers, 1889

Strauch, Alexander. The New Testament Deacon. Colorado: Lewis and Roth Publishers, 1997.

Strom, M. Bons. Apakah Pengembalaan Itu? Jakarta: BPK Gunung Mulia, 2011.

Sudarmanto, G. Menjadi Pelayan Kristus yang Baik. Malang: YPPII, 2009.

Susanto, A.B. Meneladani Jejak Yesus sebagai Pemimpin. Jakarta: PT Grasindo, 1997.

The Paul's Cross Sermons, 1534-1642. Toronto: University of Toronto Press, 1958.

The Works of John Owen, ed. William H. Goold. London: Banner of Truth Trust, 1965.
Tisnawati, Ernie \& Saefullah, Kurniawan. Pengantar Manajemen. Jakarta: Prenada Media, 2005.

Ucup, Mang. Hamba Duit VS Hamba Allah. Yogyakarta: Kairos, 2005.

Wagner, C. Peter. Doa Peperangan. Jakarta: Metanoia, 1994.

Wagner, Peter. Manfaat Karunia Roh. Malang: Gandum Mas, 2010.

Warren, Rick. Pertumbuhan Gereja Masa Kini. Malang: Gandum Mas, 2003.

Warren, Rick. The Purpose Driven Life. Malang: Gandum Mas, 2005.

Wijaya, Yakobus Handjojo. Ikabot Kemulian Allah yang Lenyap. Jakarta: 2005.

Wuwungan, O. E. Ch. Bina Warga; Bunga Rampai Pembinaan Warga Gereja. Jakarta: BPK Gunung Mulia, 2012.

Yudho, Bambang. How to Become A Christian Leader. Yogyakarta: Yayasan Andi, 2006. 